Article

\title{
Teaching and Fostering an Active Environmental Awareness Design, Validation and Planning for Action-Oriented Environmental Education
}

\author{
Daniel Thor ${ }^{1}$ and Peter Karlsudd ${ }^{2, *}$ \\ 1 Department of Visual Communications, Beckmans School of Design, 11437 Stockholm, Sweden; \\ daniel.thor@edu.beckmans.se \\ 2 Department of Pedagogy and Learning, Linnéuniversitetet, 39182 Kalmar, Sweden \\ * Correspondence: peter.karlsudd@lnu.se; Tel.: +46-705-227-392
}

Received: 3 March 2020; Accepted: 7 April 2020; Published: 16 April 2020

\begin{abstract}
In recent years, there have been frequent scientific reports focusing on high carbon dioxide emissions. Many people feel concerned about efforts not happening quickly enough to reduce the negative impact on the climate. The responsibility for reversing this trend rests primarily on adults, but hope is now directed more and more toward the younger generation. The present project, which is a collaboration between design and education, lays the foundation for an educational endeavor based on an idea of environmental citizenship. By creating environmental citizen tokens for children and youths, this project aims to change learned living patterns and encourage a new generation to work toward a sustainable climate. There is also good possibility that the young people's involvement and striving for a better environment will transfer to adults. This has become clear in the global movement started by the environmental activist, Greta Thunberg. This article describes the work of designing and preparing the implementation of a learning project, with its basis in knowledge about environmental impact and personal responsibility. The methods underlying the project are gamification and digital activities, allied with a proven system for making a progression of skills visible. The project has resulted in a finished design and an implementation plan, which have been validated through interviews with teacher educators, principals, teachers, student-teachers, parents and pupils, and which after this validation will be tested at ten specially selected Swedish compulsory schools.
\end{abstract}

Keywords: environment; climate; gamification; pupils; environmental instruction

\section{Introduction}

Global carbon dioxide emissions continue to increase and impact our planet negatively at an accelerating rate [1], which has meant that more citizens have become concerned, engaged and environmentally aware. Environmental awareness can be defined as people reflecting on their surroundings and on the role they play. A group that was previously underestimated, and in some cases completely neglected in the climate debate, consists of children and young people. Recently, Greta Thunberg has reversed this trend and turned children and young people into important players in the climate movement. Thunberg became the figurehead when she sat outside the Swedish parliament in August 2018 with her handwritten placard with the text "School strike for the climate", and went on strike every school day until the elections on September 9. The demand was for the Swedish policy to work in line with the Paris Agreement. Thunberg's actions have led to enormous publicity, which has inspired not only children and young people all over the world, but also adults, the majority with political influence [2-4]. Her actions can be seen as evidence that single individuals can have a major impact on climate policy. 
Globally, the Climate Convention makes up the framework for the interventions to prevent climate change, but without containing any binding requirements [5]. Instead, amendments have followed the Climate Convention, in the form of protocols that are legally binding on the countries that have chosen to sign them. The Kyoto Protocol [6] is one, followed by the Paris Agreement [7] that takes effect after 2020. In the Paris Agreement, the primary objective is to keep global warming at least below two degrees and preferably below 1.5 degrees. The agreement has been signed by 197 countries.

\subsection{The Individual and the Collective}

Reporting about the climate issue can essentially be divided into two orientations: either the text focuses on the climate issue as a political game (political game frame) or the reporting focuses on the substance and effects of climate change (issue frame). When reporting focuses on the political game, there is a risk that environmental issues end up in the background and that media consumers put all the responsibility on politicians and decision-makers [8]. If the reporting has an overly technical character, then technology is expected to present a successful resolution. If instead the issue is discussed as a problem that can be solved through behavioral changes, the situation opens up for the individual actually to be able to make a difference. It is from this position that the project starts. In the present model, concrete action is the midpoint. Individual positions and facts are involved in the process before and after the implementation. In this article, a more nuanced political reasoning may stem from the fact that there is a political consensus that the environment is threatened. Variations in the perception of how serious this threat is differ between policies. When it comes to the research community's concern, there is almost a unison attitude. Then, when active choices are discussed and disseminated, more are affected. When the choices are held by a larger group, it is easier to reach a political level where voters clearly express their views [9]. Inevitably there is individual responsibility. According to the Swedish Environmental Protection Agency [10], on average, each consumer produces 10 tons of carbon dioxide per person per year, with every kilogram contributing to global warming. These are figures that one can do something about at the individual level, and at the collective level they can have a great effect. Climate-smart lifestyles have a direct positive impact on the environment. For example, living car-free, eating vegetarian and having a smaller home all reduce carbon dioxide emissions [11]. Increased understanding and discussion among individual persons also puts pressure on countries and companies to be forced into formulating and following their climate goals in order to maintain credibility With reference to the risk that an excessive focus on the individual citizen's efforts will reduce the demands and focus on the major industry players, this must be acknowledged in the choice of design and method, but the work on a citizen-oriented model does not exclude other activities and efforts in connection with the project.

\subsection{Environmental Education/Environmental Awareness}

The Tbilisi Conference in 1977 [12] was an international conference on environmental awareness, which became historic when the adopted recommendations became a clear starting point for the development of environmental awareness [13]. In the conference, environmental awareness as a concept was established, and the focus was shifted from nature to the environment [14]. The recommendations and objectives that were established then are still current, describing environmental awareness as a lifelong learning process that takes place at all educational levels, as exemplified in the following citation:

- To foster clear awareness of, and concern about, economic, social, political and ecological interdependence in urban and rural areas;

- To provide every person with opportunities to acquire the knowledge, values, attitudes, commitment and skills needed to protect and improve the environment;

- To create new patterns of behavior of individuals, groups and society as a whole towards the environment [12] (p. 26). 
The purpose of environmental awareness is for people to become environmentally aware and also understand that they have their own role in relation to the environment in order to manage and protect it [14]. To achieve this aim, education is important [15], but many teachers feel the task of educating is difficult and multi-faceted [16]. To be better able to handle this task, it is important to identify how pupils relate to the environmental crisis [17]. Teacher educators and teachers must have knowledge about pupils' interests and attitudes to be better able to plan different educational interventions [18,19]. If environmental issues are to be interesting, they need to be tied to the pupils' reality $[20,21]$. Many pupils are concerned about the environment, but they have difficulty seeing that it affects their daily life to a major extent [22]. If the pupils have an overly negative outlook on the future of the environment, that can have a crippling effect instead of motivating them toward environmentally friendly behavior [23].

In recent years, the term sustainable development has come to complement and in some cases replace the terms environmental awareness and environmental education, and there is no consensus regarding the similarities and differences between the concepts [24]. Some researchers state that environmental education according to the Tbilisi Declaration contains aspects such as equality, human rights, peace, inter-cultural relations and improved health [25]. Bonnett [26] expresses concern that the curriculum emphasis on the concept of sustainable development may lead to teachers no longer taking nature sufficiently into account in their instruction. Then environmental awareness is a much deeper and better way to take on environmental issues compared to instruction for sustainable development.

The Swedish curriculum [27] states the responsibilities of schools to prepare pupils with knowledge of the conditions for a good environment and sustainable development. The curriculum highlights the importance of knowledge and understanding of the significance of one's own lifestyle for health, the environment and society. Environmental education in the Swedish schools has been around since the 1960s and is based mainly on three different traditions: fact-based, normative and pluralistic environmental education [28]. The fact-based environmental education tradition is based on subject knowledge, where pupils are taught facts grounded in science. It is thought that research should be a guide for the instruction. The fact-based teaching does not take direct regard of pupils' everyday lives; each individual can understand his or her impact on the environment through education and subject knowledge [29]. Pupils are taught about the interaction between the individual and the environment, as well as which living environments interact and what consequences these have on human living conditions. Criticism of fact-based environmental education is that action skills have a weak basis. Pupils receive no training in argumentation and valuation of democratic processes and thereby no competence to act in concrete situations [30]. The goal of the normative environmental education tradition is for pupils to embrace the norms and rules existing in society. Within the normative tradition, the role of politicians and experts becomes important and exemplified. They have the power to influence the instruction so that it follows the norms deemed just by society [28]. This orientation makes the school system a political instrument with the power to preserve or change the perceptions of society by communicating different norms and traditions to the younger citizens [31]. The normative environmental education strives to influence pupils in a direction towards a more sustainable lifestyle and makes their everyday lives clear [28]. Alongside the central content of the subject, there is the goal that pupils should be able to link ethical concepts to issues, such as those that concern sustainable development [27]. Pupils should act according to the norms that exist in society and that are developed according to what society considers to be ethically correct. Wolff [14] criticizes normative environmental education and various models of environmental education publicized as changing pupils' behavior. Instruction should not be normative, but the pupils themselves should discuss what is right and wrong. At the same time, the curriculum goals make up the basis for the instruction, and the curriculum goals cannot be achieved unless the instruction is allowed to steer in a certain direction. There is no guarantee that pupils will necessarily come to conclusions that align with the curriculum goals when they have their democratic discussions. So there are many pedagogical contradictions and dilemmas regarding the goals, theories and strategies of environmental 
education $[14,32,33]$. The pluralistic environmental education aims for pupils to learn from their own experiences and actions, where their own thoughts are valued and tested. The pupils' reflections and their possibility to think critically are emphasized. The teachers' role and the learning environment have a strong influence [34]. It is central to work with the overall subject through discussing and questioning. Pupils must gain knowledge of history to be able to understand and meet today and tomorrow [34]. In the pluralistic environmental education, pupils' everyday life and what is scientific go hand in hand by giving pupils the opportunity to evaluate and reflect on their knowledge [35]. A teacher with the pluralistic approach must be a good leader with the ability to create a permissive classroom environment where discussions and critical thinking are allowed [36]. It is a challenge as a teacher to find interesting and meaningful ways to teach a topic such as sustainable development. Educational drama may be a feasible way to stimulate the pupil to process new ideas and not just passively absorb information [37]. The present project has clear normative indications, but seeks its basis in the pluralistic approach with priority placed on the pupils' own experiences, reflections and actions.

The most effective tool for influencing human behavior and emotions is a picture that evokes positive feelings. By showing real-life problems that are easier to relate to, one is led to the assumption that one's commitment makes a difference [38]. Similar results can be found in the report entitled Children's Feelings and Thoughts on the Climate Problem [39] published by the Swedish Energy Agency. The report identifies important factors in order for children to devote themselves to environmentally friendly behavior. Knowledge of the climate issue, as well as a positive sense of being able to participate and contribute, are two of the most important elements mentioned, forming the initial basis for the goals presented below.

\section{Project Definitions and Goals}

In this project, the term environmental citizen is defined as an agreement between an individual and a larger ecosystem. Becoming an environmental citizen means one takes upon oneself the challenge as an individual of making changes in one's daily life in favor of a better environment. Based on the above background, the overriding goal is to activate children and young people in an aesthetically appealing and playful manner in working for a sustainable climate. The concrete, action-oriented goal of the project is to create several categories of "environmental citizen tokens" through a design that is instructive and to produce a plan for the implementation of the "token system" at a number of Swedish schools. In the present study, a validating pilot investigation was carried out, in which thirty people were interviewed about the project relevance and possibility of meeting the goal. In this part, important suggestions were submitted for changes in the project design and implementation.

\section{Method and Design}

The present project received much inspiration from the Swedish Life-Saving Society swimming skill pins. The swimming skill pins have been used since 1934 as motivational and educational tools for teaching water habits and swimming competence. The different pins are awarded for clear tasks that are communicated in a simple, accessible and playful way. The stated primary objectives are also included in the Swedish curriculum for water habits and swimming skills. The swimming skill pins have also served as a way of showing to others in one's surroundings what one has achieved. In many children's and youth's bedrooms, one can see how the pins are proudly displayed on a bulletin board on the wall. The Swedish Life-Saving Society has used a form of gamification even before this term was coined or defined. Gamification involves taking methods used in game design and applying them in a context that does not belong to the gaming world, for example, in teaching. Measurable progression with clear levels and immediate response are powerful tools the gaming world uses to maintain a player's interest. Applying gamification in instruction makes it much easier to identify challenges and create a stronger commitment [40]. The following text presents how the physical tokens and the environmental tasks were designed and constructed. 


\subsection{Physical Tokens}

The purpose of the physical tokens (Appendix A, Figure A1) in the project is to try to achieve a similar effect to what the Swedish Swimming Association successfully accomplishes with the swimming skill pins, but with a mission that benefits a better climate. Through the process of the project, five different tokens (Appendix A, Figure A2) with associated subject categories have crystallized: the Collector (reuse and recycle), the Squeezer (water consumption), the Explorer (ecosystem services), the Pedaler (transportation) and the Chomper (food consumption). These are names with a playful ring, intended to mark clearly various competencies in the environmental field. The names and sizes of the tokens have been inspired by their predecessors, the swimming skill pins.

\subsection{Material and Formation}

Choice of materials for the different tokens has been a challenge. Given the project deals with climate issues, there must be no wrong choices that diminish the legitimacy of the work. Early in the process, therefore, it was decided that the tokens would be manufactured primarily through the recycling of residual products and debris that can be found in nature. This ambition was possible to fulfill in three of the tokens. The other two have a direct connection to nature. An important aspect of the choice of materials for the different tokens has also been that the material should be linked to the category it represents. The process of selecting the material for each token is described below.

The Collector token (reuse and recycle) material in the end became plastic, collected from the ground in an urban environment. There was a great variety of colors in the collected plastic, which was utilized to some extent to color-coordinate the debris that was then melted down, giving rise to a fused token. The square shape in which the collector token was cast comes from a found metal piece. The Squeezer token (water consumption) material choice was not as obvious as the Collector's. Initially, a jelly substance extracted from red algae was used, for its associations with water. The consistency of the algae made it difficult to use as a token, because the jelly-like casting did not solidify. The choice instead fell upon blue clay, which is found naturally on the bottom of lakes. The design with the pointy peaks is an attempt to associate with the word "squeeze" and with aquatic creatures. The Chomper token (food consumption) choice of material became residual food waste. This led to difficulties with the rapid rate at which food waste can break down and create harmful mold cultures. Bioplastics made from a base of potato starch, therefore, became a good alternative. In addition to potatoes, it also contains coffee grounds, beets, water, glycerol and vinegar. The Pedaler token (transportation) material is coal as a symbol of the carbon dioxide emissions that transportation contributes to. The Explorer token (ecosystem services) is made from sawdust from residual material. The idea was to bring to mind thoughts of nature and have a moss-like structure. The sawdust has been put together using an adhesive consisting of water and flour, and the shape resembles a moss-covered stone.

\subsection{Token Distribution}

Like most parts of the project, ideas about the distribution of the tokens went through several alternatives. An initial thought, which also reflected the design process, was that the pupils themselves would be responsible for the production of the various tokens in order to involve and engender a creative inlet for children and young people to contribute to the design. The method would also mean that the transportation of the tokens would be reduced, compatible with the project as a whole. At the opposite end, there was the idea of being awarded uniformly manufactured tokens: a consistently designed and produced award granted for an important and successfully carried out environmental effort. This latter alternative was judged to be able to have a greater effect on commitment, recognition and status, and therefore it became the final decision. 


\subsection{Web-Based Information Aimed at a Digital Application}

In recent decades, digital tools have come to be used in more and more of our everyday activities, both in private life and working life. This is also true with school, where these tools are taking up increasingly more space in the instruction [41]. Digital technologies open up new ways of presenting and processing information, and they offer opportunities different from traditional text-based material. They enable different ways of dynamically integrating images, sounds and animations, bringing new conditions for the organization of learning activities. They are also interactive; that is, they respond to initiatives taken by the user. The digital tools thus interact with pupils' access to information and with their understanding and ways of reasoning about what they read and see. The digital application in this project is intended to function as an information carrier for the physical tokens and to introduce and guide the users toward becoming environmental citizens. Each token has a corresponding description that briefly summarizes the token's overall subject and tasks (see Appendix A, Figure A3). Below is an example of the description of the Squeezer:

"The water is not endlessly coming from our faucets as you might sometimes believe. The squeezer is about reducing water consumption and emissions to the sea. Start squeezing!".

(Appendix A, Figure A3)

In order to measure the progression clearly, as tied to the methods of gamification, each token has three associated tasks. The tasks are linked to the token's represented category, and to obtain the token, the three tasks must be carried out. In designing the tasks, the ambition was to scale down complicated facts and information. Instead, the focus was on simplifying so that the user has a low entry threshold to take on the task. Then completion varies with short-term and long-term goals. An example of a task, in this case for the Squeezer, reads as follows:

"Shower as quickly as you can. The faster the shower the more water you save"..

(Appendix A, Figure A3)

In the mentioned example, time is the measure of progression and the object of information that can be passed on to encourage others also to save water. Progression can also be measured in distance, time, number of repetitions and photo documentation depending on the character of the specific task. By uploading progress onto the app, https:/www.figma.com/proto/rZtOYVNgphv1vrAEwlkNC3/ Milj\%C3\%B6medborgare?node-id=1027\%3A101\&scaling=scale-down, the various tasks are totaled, so that an environmental citizen diploma can then be shared with friends and family. The hope is that the individual involvement will affect the group. All descriptions and tasks with the associated tokens are presented in Table A1 (Appendix A). In the digital application, the tokens have been given a color that represents the particular token. All tasks have been given a symbol intended to help the user quickly associate with the content of the task. The basic structure of the digital application can be divided into three main parts: tokens, tasks and diploma. Tokens and tasks provide the user with answers to questions of what, why and how; see Figures A2 and A3 (Appendix A). The digital diploma functions, as previously mentioned, as a summation of the completed tasks and the commitment as an environmental citizen. 


\section{Pilot Study/Validation}

Staging a project like this article describes requires planning and time for implementation. At Linnaeus University there are a large number of teacher education programs where students carry out their practicum teaching in schools. The final part of the program provides the opportunity to carry out a development-oriented thesis that centers on an action-oriented project [42,43]. A requirement for this project is that it must be based on the needs of the classroom and carried out in agreement with the staff. The development area should be relevant to the student's education profile and upcoming professional role. Important to the development-oriented projects is that the action brings about acquisition of new knowledge, contributions to development and the opportunity for lasting change. Given the objectives in the compulsory school syllabuses and the timeliness of the subject, environmental education is an appropriate area for student-teachers' endeavors, and so given a good outcome from validation, approximately 20 students at 10 practicum schools will be given the opportunity to carry out the environmental education and introduce the activities that make up the work towards environmental citizenship. The students should have good chances of acting as role models and engaging pupils at their practicum schools. If they also succeed in involving a popular figure in the activity, the endeavor will have an even more positive impact.

To increase the possibilities for obtaining the project goals, the validating pilot study was planned. With a positive result from this, the basis of the idea and the possibility for funding were considered strengthened. To validate the design and method, a number of respondents were interviewed in the areas and the target group to which the project was directed. A validation such as this can be defined as an expert and respondent validation [44]. Teacher educators, principals, teachers, student-teachers, parents and compulsory school pupils were interviewed using structured questions. In total, 30 people participated with a representation of four persons from each group, with the exception of compulsory school pupils where ten pupils were interviewed. The ages of the pupils were between six and ten years old, and both sexes were equally represented. The gender distribution in the other five groups was $75 \%$ women and $25 \%$ men. The interviews lasted between fifteen and twenty minutes and were recorded in order to be transcribed and summarized. The method used for transcription and interview analysis can be likened to what Kvale terms concentrated meaning. "Long statements are compressed into shorter statements, in which the essential meaning of what has been said is reformulated in a few words" [45] (p. 174). Through this approach, larger interview texts are reduced to shorter, concise formulations. An excessive amount of information may obscure the view of the study's purpose $[45,46]$.

The interviewees represented the areas to which the project was initially directed. Four schools are located in smaller communities, and six others are situated in a medium-sized city. The majority of the parents can be defined as middle-income earners, which is also representative for the area where the project is planned to be implemented. The interview began with an explanation of the project layout and an introduction of pictures of the tokens and task descriptions. The questions asked to the adults were the following:

1. Do you think this "token idea" can attract pupils' interest and involvement?

2. Do you see this as a suitable way toward environmental awareness (working for a better environment)?

3. What advantages (gains) do you see with this model?

4. What disadvantages (risks) do you see?

5. Which do you think is the best way to go-letting the pupils make their tokens and set the requirement levels themselves, or using the ready-designed model?

6. Are there any ethical problems connected to the project? 
The questions asked to the compulsory school pupils were the following:

1. Do you think it would be fun to get these tokens?

2. Do you think these can help in working toward a better environment?

3. What do you think is good about this idea?

4. What do you think is bad?

5. Do you want to make the tokens yourself or would it be better if they were like those in the pictures?

6. What would your mom and dad think about this idea?

7. What would your friends think about this idea?

The questions were constructed based on the project's goals and design. The interviews were conducted by two research educators who initially conducted an interview together to clarify and calibrate the questions. Since the validation study had a qualitative approach, no written questionnaire was used, and the interviews were based on open-ended interviews and therefore no co-assessor reliability can be expressed in statistical measures. Nor does the method allow measuring statistically significant differences between the various groups. When the survey was completed, the interviewees transcribed and analyzed all interviews together, and it was found that they were conducted with a high degree of coherence. It is clear that all groups are positive about the project. One slight difference is that professional teachers and teacher educators pay more attention to ethical issues in comparison with other groups.

\section{Results of Pilot Study}

\subsection{Teacher Educators}

The teacher educators believed that the environmental project could be successful and were therefore positive towards the idea and its implementation. Comments such as "All children like to earn tokens and play games" were heard from all who were interviewed. The token activities were perceived as fun, simple, thoughtful and important. Some said that this particular arrangement is best suited to children between six and twelve years old. Someone clearly remarked that "schools need help with their environmental work".

All teacher educators made suggestions for changes in the task descriptions, with the most obvious being to put a clearer focus on the pupils' own actions rather than on the surroundings. The teacher educators interviewed said that it may be hard for some families to change their behavior patterns, for example, to avoid driving a car. Some children might find it difficult when the home is involved. "Biking to school is not always an option for the child" or "should the child force dad to eat vegetarian or should the pupil lie at school" were some of the comments made. Therefore the respondents believed, for example, that the wording could be changed, such as persuade to encourage. All of them felt that one should be careful about placing guilt, and in some lessons emphasize discussion and reflection above direct action. "Then it will be not only working toward a better environment, but also an exercise in argumentation. It also must not be controlling the child, but one must rely on the child's information", stated a teacher educator. Working with a common model of tokens and task descriptions was deemed by all to be best, so that all pupils can recognize the tokens and then can discuss the tasks on social media all over the country. Creating a local token, a sixth token, with local task descriptions was also a suggestion made in this group. There were other comments provided:

"You have to think what is in the foreground and the background. Is it the environmental issues or the pursuit of tokens?

It is important that this is part of a larger context and not just an isolated activity, so that you incorporate this in subject instruction. This should not be just a fun happening". 


\subsection{Principals}

Interviewed principals thought the idea was simple, clear and concrete. Everyone believed that it was a good way to raise awareness about environmental issues. All those interviewed stated that the tasks feel absolutely feasible, and it is good to get some concrete proof of one's efforts (the tokens). The tokens were perceived as "clever". One principal said that if the tokens are considered as rewards, then one should receive them and not have to make them oneself. This type of project is best suited for pupils between six and ten years old according to the principals, as shown by the following quotation:

"A little old-fashioned. It will be a limited age group that is attracted to the model. Age six to ten is best. If it is digital, you can certainly create an interest further up in age".

"Nice tokens?" "How big are they?" "Can you put them on your clothes?"

The interviewed principals thought it was perfectly fine for the tasks to be carried out at home as long as they are not violating privacy.

\subsection{Teachers from Elementary School}

The classroom teachers who were interviewed were positive about the design and thought that the project could engage pupils. Some arguments heard were that this is "a good step toward raising awareness for environmental efforts by children and adults. The tokens are going to spur on the children. Interest grows and the goal is clear to get the token when you have completed the tasks". Other expressed opinions were that "the children are going to feel it is a luxury to get the tokens, so we should not make them ourselves. It is wise to manufacture the tokens out of recycled materials. If the pupils make the tokens themselves, there is a risk that some become disappointed if they feel their own tokens came out ugly". Additionally, the teachers did not see any direct difficulty with doing several tasks in the home setting, but agreed that it may be wise to review the task descriptions so that they do not arouse any ill feelings and dissatisfaction. One teacher ended the interview with the following statement:

"Great idea! We want to do this at our school!"

\subsection{Student-Teachers}

Asked whether a project like this could be rewarding, all of the student-teachers replied that it was a good idea. "A fun thing". Everyone thought they could work with this during their practicum. One problem that was brought up was how performance should be checked. "Who checks whom" was one student comment. The student-teachers thought the project should be more directed toward groups, mainly with the idea that no one should feel incompetent or left out. "Best not to put pressure on the individual child". All were in agreement about it being most important to raise the consciousness of the pupils. The students believed it was more about building up motivation for the activities than earning the tokens. Making a larger story and introducing the project using a "YouTube film" was another suggestion proposed.

\subsection{Parents}

All parents were positive about the idea, but in this group there were more reservations and sympathy for the children who might encounter negative reactions at home. For the children who can discuss with their parents and maybe come to agreement about changing behavior patterns, all the tasks are fine. For other children, there might be more of a struggle if the tasks are seen as provocative. Some children may be ashamed or feel guilty if they do not succeed in carrying out a task at home. The parents said that the project could also create disagreements among friends if the tasks are difficult to complete at home. Some parents testified how much importance children's views have on the family's behavior. The children could get parents to refrain from a trip abroad or buying new clothing. Some children were already involved in environmental projects with competition-like 
activities, for example, returning deposit bottles where the result was presented in terms of reduced carbon dioxide impact. One parent believed it could be good not to have the activities connected to a digital app, because a number of children do not have access to a smartphone or a computer. "It is good enough to make a note in a book", stated the same parent. All parents felt that getting the manufactured tokens was the best way to go. One parent thought that "many children have anxiety about the climate" and that they would think it was nice to do something concrete that is acknowledged with an award. "The children are waiting to get to do something. They want to do something".

One parent stated there was some potential for development of the project. Developing a game targeting children in the older age group could be a way to go. Another idea presented was a collective effort involving school classes competing against each other.

\subsection{Pupils}

The group making up the main players in the project consists of pupils in elementary school; therefore, ten pupils aged six to ten years old were interviewed. The pupils were a little more reserved in their responses than the previous interviewees, but all were positive and stated that the project could do some benefit for the environment. "It certainly helps, but not the whole world", commented one pupil. Some expressed that they could be "fun tasks" to do, while two pupils perceived it more as a competition. One pupil asked and commented, "Do you have to get all the tokens? I cannot get that token (pedaler), because I am taking a plane on my holiday. But the Squeezer I can take!" No one interviewed expressed any concern for what friends would think. The pupils stated that if the task was from school, then it didn't matter what their friends thought; "then of course everyone does the assignment". On the question about what parents would think about the tasks, the answers were favorable. One example of an answer was that "mom and dad don't have anything against homework from school". "They are good things to do and we eat vegetarian sometimes" was another comment. "I think my parents believe this is a smart idea" was a further comment. Many comments were about the tasks. "I can easily do a quick shower at school. I shower very quickly after gym class, but the teacher might not think that is so good", said one pupil. Many of the interviewees thought they could work more in groups. One pupil expressed it like this: "It can be hard to write a letter to the principal. It is better that everyone in the class does that". An example of a task suggested as appropriate to do in a group was the insect hotel, stated one pupil and continued, "The insect hotel is good, because the insects are dying out. Maybe one has to show how to build it".

Many pupils related the tasks to the gaming world and gave creative suggestions on how the game could be developed. One pupil focused on the points in the tasks and asked the question, "How many points can you get?" The same person even discovered there was a mistake in the points of one of the tasks. Some brought up the risk of cheating, or that one could just do the minimum. "Maybe you only do as much as you need to get the token" was one comment. One pupil who had the idea presented for her thought that there could be a base token that shows one is environmentally aware, and thereafter one could continue to earn more tokens. These are other examples of comments heard from pupils:

"It is good to do tasks in nature. You get some exercise then. Good for the body".

"It is good to get points and work to help nature-you should not take advantage of nature".

"It would be fun if the tokens changed according to different seasons, so there would be new tasks after a while". 


\section{Discussion}

This work of planning for an upcoming environmental education project has involved an interesting and informative collaboration between design and pedagogy. The goal has been to create, through a combination of learning theories [28,40], an aesthetically appealing and fun teaching material, which can be used as a component in environmental education. In the present work, a validating pilot study has been the main feature. Important viewpoints for improvements and modifications have been submitted in interviews with teacher educators, principals, teachers, student-teachers, parents and pupils; at the same time, clear support for implementation of the project has been underscored. The interviews with the teacher educators, teachers and student-teachers confirm the professionals' stance that working with environmental education is important $[14,15]$. The game design that the project is based upon, and which the interviewees recognize, is an example of linking to the pupils' interests and needs, which according to several studies is a condition for successful environmental education [18-21]. Some parents have expressed that children are concerned, and they believe it is important for children to get the opportunity to act in an environmentally conscious manner and at the same time receive recognition for their efforts. These are measures that earlier research has recommended $[22,23]$. The project has elements of fact-based, normative and pluralistic environmental education [28]. The pluralistic environmental education has been the guide, setting a strategy that aims for pupils to learn based on their own experiences, actions and reflections. Some respondents, similar to Wolff [14], have warned that an overly normative and aligned task can create ethical problems. As a consequence, some tasks will be adjusted in order to be more individual and have more of an argumentative, reflective and encouraging character. One task that can be perceived as a heavy demand on another family member is, for example, "persuade an adult to take the train instead of flying". Here persuade can be replaced with the formulation "discuss taking the train instead of flying". In this validating study, the respondents have represented an area with relatively good economic conditions. This is the same area where the introductory work with the project is planned to start. Before introducing the project in another area with a weaker socio-economic structure, there may be reason to redo the validation study.

It is a balancing act to work with rewards that are coupled to performance and, at the same time, not exclude children and young people who do not have the same opportunity to achieve the goals. Therefore, it felt important for everyone to have the possibility to call himself or herself an environmental citizen even before the tasks have been completed at all levels. It should be sufficient to have an honest will to take on the challenges, and the tokens should function as a proof of commitment rather than as a reward for achievement. A subject like climate change requires questioning one's actions time and time again in the form of choices and formulations. Initially in the project, the main interest was directed toward the physical tokens and their symbolism. The digital application in the future could become more central and have more features. It can be made even more game-oriented and, for example, contain a discussion forum where environmental citizens can communicate.

The greatest hope with the environmental citizen tokens is that in the long run they will have an obvious place in the Swedish school system, just like the swimming skill pins, and have the same measurable effect on a climate-smart lifestyle as, for example, the swimming skills have. The desire is that environmental citizenship will help the coming generation with concrete action to work for a better climate. 
Finally, we would like to encourage other schools to work with the idea of environmental citizenship. Engaging pupils more in the preparatory work with design, task descriptions, production and implementation can at best be an even better idea. It is important to adapt the requirements, tasks and names of the tokens according to the differing conditions in different areas and countries. Based on a very large number of researchers, it is an indisputable fact that efforts must happen quickly and on a broad front. In the projects that are now being planned, validated and shortly launched, new research questions will be formulated. Some of these will take into account pupils' perceptions and thoughts about the future and about environmental interventions. Our hope is that this work will inspire and strengthen knowledge in the field of environmental education.

Author Contributions: Conceptualization, D.T.; methodology, D.T. and P.K.; software, D.T.; validation, P.K.; formal analysis, P.K.; investigation, P.K.; resources, D.T. and P.K.; data curation, D.T. and P.K.; writing-original draft preparation, D.T. and P.K.; writing-review and editing, P.K. and D.T.; visualization, D.T. All authors have read and agreed to the published version of the manuscript.

Funding: This research received no external funding, but was funded within the budgets of the two collaborating universities.

Conflicts of Interest: The authors declare no conflict of interest.

\section{Appendix A}

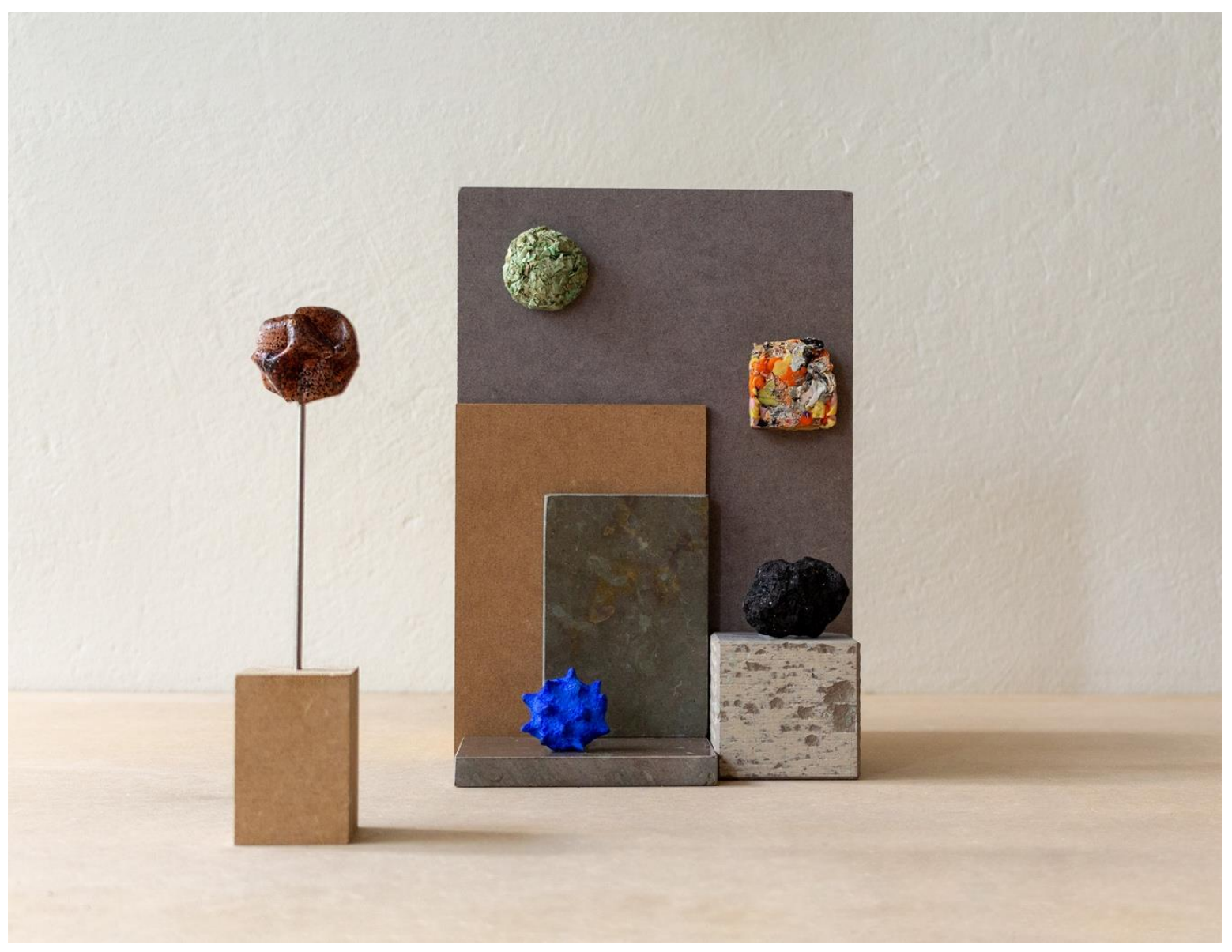

Figure A1. Physical tokens. 


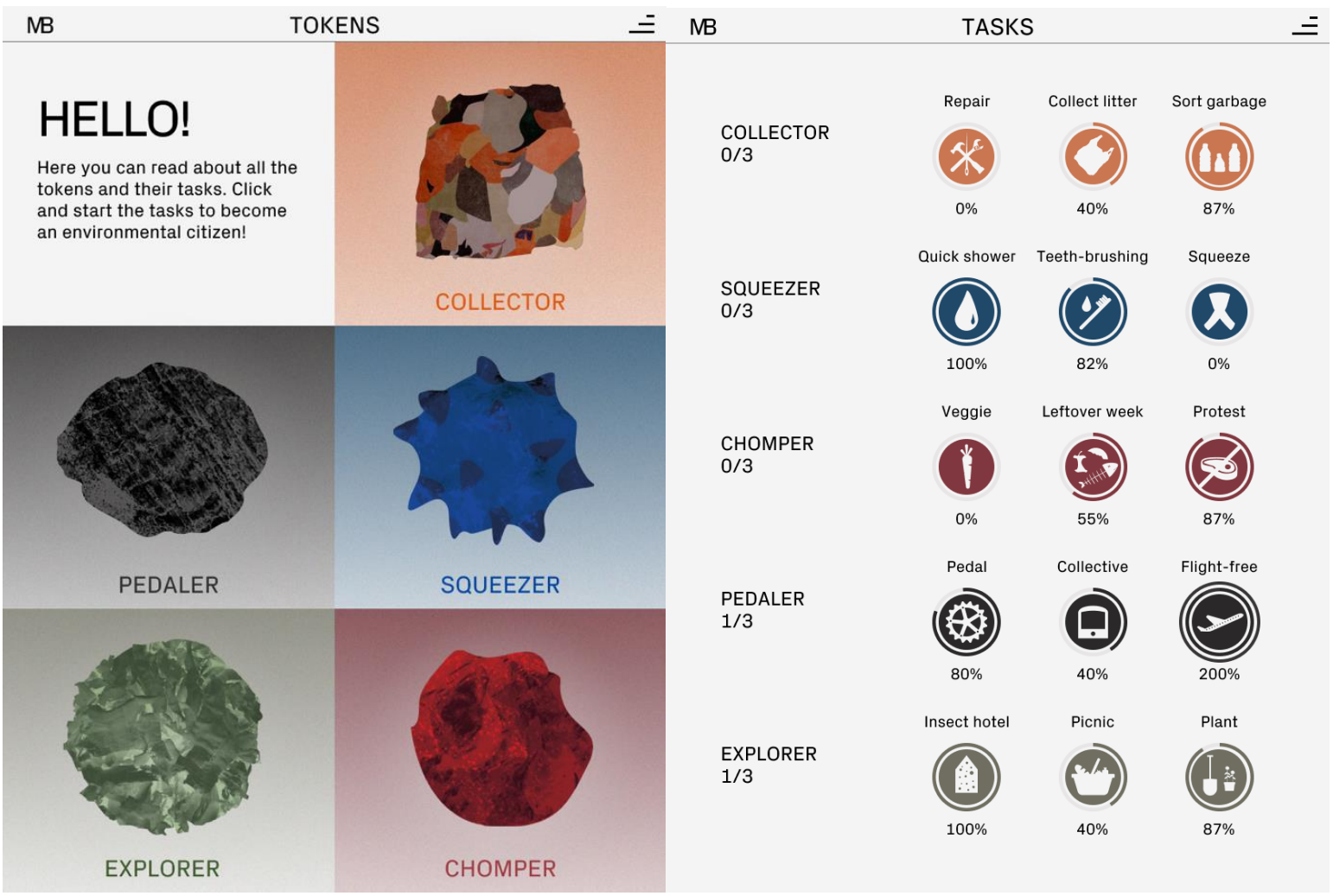

Figure A2. Overview page, tokens.

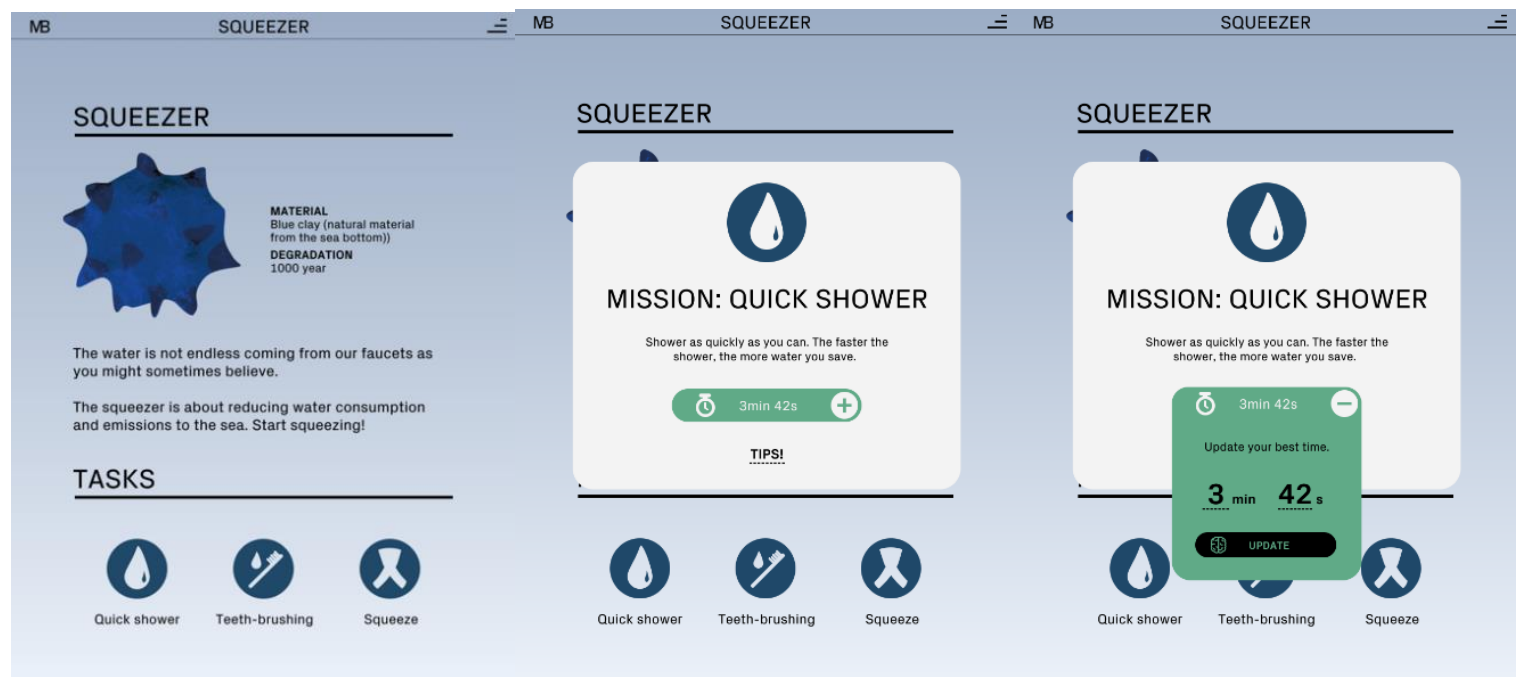

Figure A3. Example of the token Squeezer with associated tasks. 
Table A1. Text to the tokens with associated descriptions and tasks.

\begin{tabular}{|c|c|c|c|c|c|}
\hline & Collector & Explorer & Squeezer & Chomper & Pedaler \\
\hline Description & $\begin{array}{l}\text { Nature is full of litter, and } \\
\text { we buy a lot of new stuff } \\
\text { despite many gadgets are } \\
\text { still usable. The collector } \\
\text { is about reusing things we } \\
\text { thought couldn't be used } \\
\text { anymore. Collect! }\end{array}$ & $\begin{array}{l}\text { We feel good when we spend } \\
\text { time outdoors, but despite } \\
\text { that we spend most of our } \\
\text { time indoors. The explorer is } \\
\text { about going out in nature } \\
\text { andlearning more about } \\
\text { animals and nature. Explore } \\
\text { more! }\end{array}$ & $\begin{array}{l}\text { The water is not endless } \\
\text { coming from our faucets as } \\
\text { you might sometimes believe. } \\
\text { The squeezer is about } \\
\text { reducing water consumption } \\
\text { and emissions to the sea. Start } \\
\text { squeezing! }\end{array}$ & $\begin{array}{l}\text { The chomper is about } \\
\text { reducing the amount of food } \\
\text { that gets thrown away and } \\
\text { also eating food that is good } \\
\text { for the environment and } \\
\text { ourselves. Chomp! }\end{array}$ & $\begin{array}{l}\text { It is better for the } \\
\text { environment to bike and walk } \\
\text { than to drive a car, and many } \\
\text { times we use the car } \\
\text { unnecessarily. The pedaler is } \\
\text { about reducing emissions that } \\
\text { come from transportation. } \\
\text { Pedal! }\end{array}$ \\
\hline Material & $\begin{array}{l}\text { Plastic (plastic garbage } \\
\text { collected from nature) }\end{array}$ & $\begin{array}{l}\text { Sawdust (remaining particles } \\
\text { after wood has been sawed) }\end{array}$ & $\begin{array}{l}\text { Blue clay (natural material } \\
\text { from the sea bottom) }\end{array}$ & $\begin{array}{l}\text { Plastic made from food } \\
\text { remains (potatoes, beets, } \\
\text { coffee grounds, vinegar and } \\
\text { glycerol) }\end{array}$ & Coal (residual product) \\
\hline $\begin{array}{l}\text { Tasks } \\
1 .\end{array}$ & $\begin{array}{l}\text { Make sure everyone in the } \\
\text { family sorts the garbage. } \\
\text { Garbage can have a new } \\
\text { life if it is reused in the } \\
\text { right way. Sort more! }\end{array}$ & $\begin{array}{l}\text { Build an insect hotel. Insects } \\
\text { have a hard time finding some } \\
\text { place to live. Help them! }\end{array}$ & $\begin{array}{l}\text { Don't let the water run. Turn } \\
\text { it off when you brush your } \\
\text { teeth and remind adults to do } \\
\text { the same. }\end{array}$ & $\begin{array}{c}\text { Eat more vegetarian and skip } \\
\text { the meat. If we change the } \\
\text { way we eat, we can help the } \\
\text { environment. }\end{array}$ & $\begin{array}{l}\text { Walk or bike to school, to go } \\
\text { see your friends and to } \\
\text { training. If you ride your bike } \\
\text { instead of going by car, both } \\
\text { you and the environment will } \\
\text { feel better. Cycle more! }\end{array}$ \\
\hline 2. & $\begin{array}{l}\text { Repair a broken gadget or } \\
\text { mend a torn garment. } \\
\text { Then we save energy and } \\
\text { resources. }\end{array}$ & $\begin{array}{l}\text { Prepare some refreshments } \\
\text { and take your family and } \\
\text { friends out for a picnic in } \\
\text { nature. Many feel happier } \\
\text { when they spend time in } \\
\text { nature. }\end{array}$ & $\begin{array}{c}\text { Shower as quickly as you can. } \\
\text { The faster the shower, } \\
\text { the more water you save. }\end{array}$ & $\begin{array}{l}\text { Take only as much food as } \\
\text { you can eat. That way we do } \\
\text { not throw away food } \\
\text { unnecessarily. }\end{array}$ & $\begin{array}{l}\text { Use public transportation or } \\
\text { share rides with friends. } \\
\text { The more people travel } \\
\text { together, the less emissions } \\
\text { there are. }\end{array}$ \\
\hline 3. & $\begin{array}{l}\text { Collect litter on the street } \\
\text { where you live, near the } \\
\text { school or in another place } \\
\text { that needs your help. } \\
\text { Then recycle the garbage } \\
\text { you collect so that it ends } \\
\text { up where it should. }\end{array}$ & $\begin{array}{c}\text { Plant one or more plants on } \\
\text { the balcony, in the schoolyard } \\
\text { or any other place in nature. } \\
\text { Then you help insects feel } \\
\text { better. }\end{array}$ & $\begin{array}{l}\text { Do not go pee in the sea when } \\
\text { you are swimming, but go on } \\
\text { land instead. Urine is best on } \\
\text { land. In the sea it contributes } \\
\text { to eutrophication. }\end{array}$ & $\begin{array}{l}\text { Write an email with the class } \\
\text { to the principal that the } \\
\text { school should have several } \\
\text { vegetarian days a week. } \\
\text { The principal may not know } \\
\text { we need to eat more } \\
\text { vegetarian for the } \\
\text { environment. }\end{array}$ & $\begin{array}{l}\text { Persuade an adult to take the } \\
\text { train instead of flying. It's } \\
\text { better for the environment to } \\
\text { stay on the ground. }\end{array}$ \\
\hline
\end{tabular}




\section{References}

1. Figueres, C.; Le Quéré, C.; Mahindra, A.; Bäte, O.; Whiteman, G.; Peters, G.; Guan, D. Emissions are still rising: Ramp up the cuts. Nature 2018, 564, 27-30. [CrossRef] [PubMed]

2. Lewis, S. Pope Francis Encourages Teen Climate Activist Greta Thunberg to Continue Her Fight. CBS News. 2019. Available online: https://www.cbsnews.com/news/pope-francis-encourages-teen-climate-activistgreta-thunberg-to-continue-fight/ (accessed on 17 April 2019).

3. Svan, C. Barack Obama Hyllar Greta Thunberg [Barack Obama praises Greta Thunberg]. Dagens Nyheter. 2019. Available online: https:/www.dn.se/nyheter/varlden/barack-obama-hyllar-greta-thunberg/ (accessed on 23 April 2019).

4. Rankin, J. Forget Brexit and Focus on Climate Change, Greta Thunberg Tells EU. The Guardian. 2019. Available online: https://www.theguardian.com/environment/2019/apr/16/greta-thunberg-urges-eu-leaderswake-up-climate-change-school-strike-movement (accessed on 16 April 2019).

5. United Nations. United Nations Framework Convention on Climate Change; United Nations: Rio de Janeiro, Brazil, 1992.

6. United Nations. Kyoto Protocol to the United Nations Framework Convention on Climate Change; United Nations: Kyoto, Japan, 1998.

7. United Nations. Paris Agreement to the United Nations Framework Convention on Climate Change; United Nations: Paris, France, 2016.

8. Roosvall, A.; Tegelberg, M. Media and Transnational Climate Justice: Indigenous Activism and Climate Politics; Peter Lang Publishing Inc.: New York, NY, USA, 2018.

9. Wolrath-Söderberg, M. Kritisk självreflektion i komplexa frågor: Att hjälpa studenterna att ta makten över sitt tänkande [Critical self-reflection on complex issues: Helping students take power over their thinking]. Högre Utbild. 2017, 2, 77-90.

10. Naturvårdsverket. Konsumtionsbaserade Växthusgasutsläpp Per Person Och År [Consumption-Based Greenhouse Gas Emissions Per Person and Year]; Naturvårdsverket: Stockholm, Sweden, 21 March 2019.

11. Akenji, L.; Lettenmeier, M.; Koide, R.; Toivio, V.; Amellina, A. 1.5-Degree Lifestyles: Targets and Options for Reducing Lifestyle Carbon Footprints; Institute for Global Environmental Strategies: Hayama, Japan, 2019.

12. UNESCO. First Interngovernmental Conference on Environmental Education; Final Report; UNESCO: Tbilisi, Georgia; Paris, France, 1978; Available online: http://www.gdrc.org/uem/ee/EE-Tbilisi_1977.pdf (accessed on 31 January 2020).

13. Palmer, J.A. Environmental Education in the 21st Century. Theory, Practice, Progress and Promise; Routledge: London, UK, 1998.

14. Wolff, L. Nature and Sustainability. An Educational Study with Rousseau and Foucault; Diss. Saarbrücken; LAP Lambert Academic Publishing: Saarbrücken, Germany, 2011.

15. Scott, W.; Gough, S. Sustainable Development and Learning. Framing the Issues; RoutledgeFalmer: London, UK, 2003.

16. Kimaryo, L. Integrating Environmental Education in Primary School Education in Tanzania. Teachers' Perceptions and Teaching Practices; Diss. Åbo; Åbo Akademi University Press: Turku, Finland, 2011.

17. Barraza, L. Perception of social and environmental problems by English and Mexican school children. Can. J. Environ. Educ. 2001, 6, 139-157.

18. Jenkins, E.W.; Pell, R.G. Me and the environmental challenges: A survey of English secondary school students' attitudes towards the environment. Int. J. Sci. Educ. 2006, 28, 765-780. [CrossRef]

19. Rickinson, M. Researching and understanding environmental learning: Hopes for the future. Environ. Educ. Res. 2006, 12, 445-457. [CrossRef]

20. Lundegård, I. Self, values and the world-Young people in dialogue on sustainable development. In Values and Democracy in Education for Sustainable Development—Contributions from Swedish Research; Öhman, J., Ed.; Liber: Stockholm, Sweden, 2008; pp. 123-144.

21. Schroeder, H.W. Place experience, gestalt, and the human-nature relationship. J. Environ. Psychol. 2007, 27, 293-309. [CrossRef]

22. Haluza-Delay, R. Nothing here to care about: Participant constructions of nature following a 12-day wilderness program. J. Environ. Educ. 2001, 32, 43-48. [CrossRef] 
23. Ojala, M. Hope and Worry: Exploring Young People's Values, Emotions, and Behavior Regarding Global Environmental Problems; Diss. Örebro Studies in Psychology 11. Ph.D. Thesis, Örebro Universitet, Örebro, Sweden, 2007.

24. Tani, S.; Cantell, H.; Koskinen, S.; Nordström, H.; Wolff, L. Kokonaisvaltaisuuden haaste-Näkökulmia ympäristökasvatuksen kulttuuriseen ja sosiaaliseen ulottuvuuteen. [Holism as a challenge-Perspectives on the cultural and social dimension of environmental education]. Kasvatus 2007, 38, 199-211.

25. Sureda Negre, J.; Calvo Sastre, A. Environmental education. In Sustainable Development and Intercultural Sensitivity. New Approaches for a Better World; Miranda, B., Alexandre, F., Ferreira, M., Eds.; Universidade Aberta: Lisbon, Portugal, 2004; pp. 33-40.

26. Bonnett, M. Environmental education and the issue of nature. J. Curric. Stud. 2007, 39, 707-721. [CrossRef]

27. Lgr 11. Läroplan för Grundskolan, Förskoleklassen Och Fritidshemmet [Curriculum for Compulsory School, Kindergarten and After-School Leisure Program]; Skolverket: Stockholm, Sweden, 2018.

28. Öhman, J. Moral perspectives in selective traditions of environmental education. In Learning to Change Our World; Wickenberg, P., Ed.; Studentlitteratur: Lund, Sweden, 2004; pp. 33-58.

29. Zenelaj, E. Education for sustainable development. Eur. J. Sustain. Dev. 2013, 2, 227-232.

30. Öhman, J. Environmental ethics and democratic responsibility-A pluralistic approach to ESD. In Values and Democracy in Education for Sustainable Development_Contributions from Swedish Research; Öhman, J., Ed.; Liber: Stockholm, Sweden, 2008; pp. 17-32.

31. Wickenberg, P. Norm supporting structures in environmental education and education for sustainable development. In Learning to Change Our World; Wickenberg, P., Ed.; Studentlitteratur: Lund, Sweden, 2004; pp. 103-127.

32. Grace, M.; Sharp, J. Exploring the actual and potential rhetoric-reality gaps in environmental education and their implications for pre-service teacher training. Environ. Educ. Res. 2000, 6, 332-344. [CrossRef]

33. Stevenson, R.B. Schooling and environmental education: From discourses of policy and practice to discourses of professional learning. Environ. Educ. Res. 2007, 13, 265-285. [CrossRef]

34. Björneloo, I. Innebörder av Hållbar Utveckling: En Studie av Lärares Utsagor om Undervisning [Meanings of Sustainable Development: A Study of Teachers' Statements about Instruction]; Göteborgs Universitet: Gothenburg, Sweden, 2007.

35. Öhman, J. Att Utbilda för Hållbar Utveckling: Ett Pluralistiskt Perspektiv [Educating for Sustainable Development: A Pluralistic Perspective]; Konferensbidrag vid Nycklar Till Framtiden—Lärande för Hållbar Utveckling: Nyköping, Sweden, 2009; pp. 18-19.

36. Almers, E. Handlingskompetens för Hållbar Utveckling-Tre Berättelser Om Vägen Dit [Action Competence for Sustainable Development-Three Stories about the Way There]; School of Education and Communication: Jönköping, Sweden, 2009; p. 6.

37. McNaughton, M.J. Educational drama in education for sustainable development: Eco-pedagogy in action. Pedagog. Cult. Soc. 2010, 18, 289-308. [CrossRef]

38. O'Neill, S.; Nicholson-Cole, S. "Fear Won't Do It" Promoting Positive Engagement With Climate Change Through Visual and Iconic Representations. Sci. Commun. 2009, 30, 355-379. [CrossRef]

39. Ojala, M. Barns Känslor Och Tankar Om Klimatproblemen [Children's Feelings and Thoughts about the Climate Problem]; Energimyndigheten: Örebro, Sweden, 2010.

40. Huang, W.; Soman, D.A. Practitioner's Guide to Gamification of Education; Rotman School of Management: Toronto, ON, Canada, 2013.

41. Lantz-Andersson, A.; Säljö, R. Lärande i den Uppkopplade Skolan [Learning in the Online School]; Gleerups: Malmö, Sweden, 2014.

42. Karlsudd, P.; Dahl, M.; Willén-Lundgren, B. Less tradition for more profession: An attempt with thesis projects in practical development. Probl. Educ. 21st Century 2017, 75, 252-262.

43. Karlsudd, P. Swedish Student-Teachers in Digital Activities: Digital Competence through Development-Oriented Thesis Projects. Int. J. Comput. Sci. Inf. Technol. 2019, 11. [CrossRef]

44. Holmberg, L. Tankar om Validitet. [Thoughts on Validity] (Rostadtryck); Lärarhögskolan: Kalmar, Sweden, 1993. 
45. Kvale, S. Den Kvalitativa Forskningsintewjun [The Qualitative Research Interview]; Studentlitteratur: Lund, Sweden, 1997.

46. Karlsudd, P. Inkluderande individualisering [Inclusive individualization]. Specialpædagogik 2015, 35, 24-36. 